\title{
Uptake of Major Nutrients of White Sorghum as Influenced by Irrigations and Different Levels of Nitrogen at Post-Harvest Stage
}

\author{
T. Swami Chaitanya*, P. Munirathnam, M. Srinivasa Reddy and P. Kavitha \\ Department of Agronomy, Agricultural College, Mahanandi, Kurnool, ANGRAU, (A.P.), India \\ *Corresponding author
}

\begin{tabular}{|c|c|}
\hline & A B S T R A C T \\
\hline $\begin{array}{l}\text { Nutrients uptake, } \\
\text { Concentration, } \\
\text { Irrigation. }\end{array}$ & \multirow{3}{*}{$\begin{array}{l}\text { Field experiment was conducted at Regional Agricultural Research Station, } \\
\text { Nandyal during post rainy season (maghi), } 2015-16 \text { to study the response of } \\
\text { white sorghum to irrigations and nitrogen levels. The results of the } \\
\text { experiment revealed that the higher concentration and uptake of major } \\
\text { nutrient were obtained with the application of } 180 \mathrm{~kg} \mathrm{~N} \mathrm{ha}^{-1} \text { than } 120,150 \\
\text { and } 180 \mathrm{~kg} \mathrm{~N} \mathrm{ha}^{-1} \text {. In case of irrigations the higher values with two } \\
\text { irrigation which was significantly higher than one irrigations and no } \\
\text { irrigation. The interaction between nitrogen and irrigation levels was non- } \\
\text { significant in concentrtion and uptake of major nutrients. }\end{array}$} \\
\hline Article Info & \\
\hline $\begin{array}{l}\text { Accepted: } \\
\text { 10 September } 2017 \\
\text { Available Online: } \\
10 \text { November } 2017\end{array}$ & \\
\hline
\end{tabular}

\section{Introduction}

Sorghum [Sorghum bicolor(L.) Moench] is the world's fifth major crop in terms of production and acreage. It is a staple food crop for millions of the poorest and most food insecure people in the semi-arid tropics of Africa, Asia and Central America. Sorghum is a highly reliable crop that grows well in hot and dry environments. It is "climate changeready" crop and provides food security and income for millions of poor farmers. Rabi sorghum (post rainy season) has multifaced problems. Irrigation is one of the most important factors that play a important role in sorghum production. As the crop is raised mostly under rainfed condition with the help of stored moisture, the moisture deficit, especially during later stages of crop growth poses a serious threat to the crop, consequently the yield levels of rabi sorghum are very low. In Kurnool district, sowings are generally taken up during post rainy season called maghi (middle of September to middle of October). Two situations are prevailing in Kurnool district i.e., in some areas sorghum is completely grown under rainfed conditions whereas in canal ayacut areas, one or two irrigations are being given. Further, under KC canal, it would be very difficult to predict the availability of water for irrigation as the stage of irrigation is very important. Therefore, it is very important to find out how many irrigations can be provided under limited irrigated conditions under $\mathrm{KC}$ canal ayacut area for enhancing productivity. Farmers generally go for blanket application of nitrogenous fertilizers without actually 
knowing the requirement of crop particularly if the crop is irrigated. Irrespective of the situation (whether rainfed or irrigated) farmers indiscriminately use nitrogenous fertilizers for sorghum. Further, newly developed varieties with high yield potential required additional doses of nitrogen fertilizers due to their fertilizer responsive nature. Hence, the present study was conducted to study the effect of irrigations and nitrogen levels on growth and yield of sorghum during post rainy (maghi) season.

\section{Materials and Methods}

Field experiment was conducted during post rainy season (maghi) 2015-16 at RARS, Nandyal. The experimental soil was clay in texture, and it was moderately alkaline in reaction with a $\mathrm{pH}$ of $8.6, \mathrm{EC}$ of $0.15 \mathrm{dSm}^{-1}$, low in organic carbon $(0.57 \%)$ and low in available nitrogen $\left(146.2 \mathrm{~kg} \mathrm{ha}^{-1}\right)$, medium in available phosphorus $\left(33.2 \mathrm{~kg} \mathrm{ha}^{-1}\right)$ and high in potassium $\left(395.6 \mathrm{~kg} \mathrm{ha}^{-1}\right)$. The experiment was laid out in split plot design with three replications and treatment combinations of three irrigation levels and four nitrogen levels making twelve treatments. The three irrigation levels viz., no irrigation (rainfed), one irrigation and two irrigations and four nitrogen levels viz., 90, 120, 150 and $180 \mathrm{~kg}$ $\mathrm{N} \mathrm{ha}^{-1}$. Recommended dose of phosphorus (40 $\mathrm{kg} \mathrm{ha}^{-1}$ ) and potassium (30 $\mathrm{kg} \mathrm{ha}^{-1}$ ) were applied uniformly to all the treatments. Nitrogen was applied in two equal splits. Half of nitrogen along with full dose of phosphorus and potassium was applied as basal at the time of sowing. The remaining quantity of nitrogen was top dressed at knee-height stage of crop. plants were sampled at monthly interval from the sample rows which were allotted for destructive sampling.

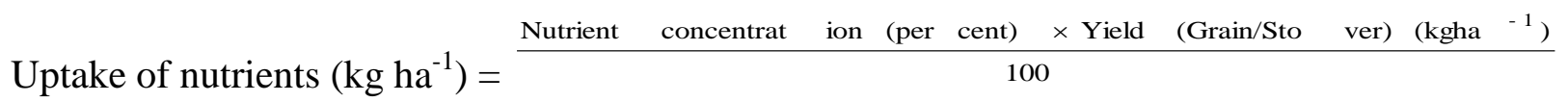

\section{Results and Discussion}

\section{Nutrient Uptake}

\section{Nitrogen uptake $\left(\mathrm{kg} \mathrm{ha}^{-1}\right)$}

The data on nitrogen uptake by sorghum as influenced by irrigation levels and different nitrogen levels are furnished in Table 1. Higher uptake of nitrogen in the grain was recorded with two irrigations $\left(83.4 \mathrm{~kg} \mathrm{ha}^{-1}\right)$ which was significantly superior over no irrigation (44.7 $\mathrm{kg} \mathrm{ha}^{-1}$ ) but statistically comparable with one irrigation $\left(81.4 \mathrm{~kg} \mathrm{ha}^{-1}\right)$.

Two irrigations recorded significantly higher uptake of nitrogen $\left(110.7 \mathrm{~kg} \mathrm{ha}^{-1}\right)$ in stover than one irrigation $\left(63.4 \mathrm{~kg} \mathrm{ha}^{-1}\right)$ and no irrigation (60.5 $\left.\mathrm{kg} \mathrm{ha}{ }^{-1}\right)$. However, no irrigation and one irrigation were on par with each other. Higher uptake of nitrogen can be correlated with lower availability of nitrogen in the soil. Significant improvement in the uptake of nutrients might be attributed to better availability of nutrients in the soil under non competitive environments with the irrigation levels (Mathukia et al., 2014).

With each incremental increase in nitrogen levels from 90 to $180 \mathrm{~kg} \mathrm{~N} \mathrm{ha}^{-1}$ uptake of nitrogen was increased. Maximum nitrogen uptake of $78.2 \mathrm{~kg} \mathrm{ha}^{-1}$ was recorded with 180 $\mathrm{kg} \mathrm{N} \mathrm{ha}^{-1}$ in the grain which was on par with $150 \mathrm{~kg} \mathrm{~N} \mathrm{ha}^{-1}$ (72.4 $\mathrm{kg} \mathrm{ha}^{-1}$ ) and significantly lower uptake was recorded with 90 and 120 $\mathrm{kg} \mathrm{N} \mathrm{ha}^{-1}$ and which were comparable with each other. Higher nitrogen uptake in the stover was recorded with $180 \mathrm{~kg} \mathrm{~N}^{-1}(86.3$ $\mathrm{kg} \mathrm{ha}^{-1}$ ) which was on par with 150 and $120 \mathrm{~kg}$ $\mathrm{N}$ ha $^{-1}$ and significantly lower uptake was recorded with $90 \mathrm{~kg} \mathrm{~N} \mathrm{ha}^{-1}\left(65.6 \mathrm{~kg} \mathrm{ha}^{-1}\right)$. 
Table.1 Concentration (\%) and uptake of major nutrients $\left(\mathrm{kg} \mathrm{ha}^{-1}\right)$ of white sorghum as influenced by irrigations and different nitrogen levels

\begin{tabular}{|c|c|c|c|c|c|c|c|c|c|c|c|c|c|c|}
\hline \multirow[t]{2}{*}{ Treatments } & \multicolumn{2}{|c|}{\begin{tabular}{|c|} 
Concentration \\
N\% \\
\end{tabular}} & \multicolumn{2}{|c|}{$\begin{array}{c}\text { Uptake N } \\
\left(\mathrm{kg} \mathrm{ha}^{-1}\right)\end{array}$} & \multicolumn{2}{|c|}{$\begin{array}{c}\text { Concentration } \\
\text { P\% } \\
\end{array}$} & \multicolumn{2}{|c|}{$\begin{array}{c}\text { Uptake } \\
\text { P }\left(\text { kg ha }^{-1}\right) \\
\end{array}$} & \multicolumn{2}{|c|}{$\begin{array}{c}\text { Concentration } \\
\mathbf{K} \% \\
\end{array}$} & \multicolumn{2}{|c|}{$\begin{array}{r}\text { K uptake } \\
\left(\mathrm{kg} \mathrm{ha}^{-1}\right)\end{array}$} & \multirow{2}{*}{$\begin{array}{c}\text { Grain } \\
\text { yield } \\
\left(\mathrm{kg} \mathrm{ha}^{-1}\right)\end{array}$} & \multirow{2}{*}{$\begin{array}{l}\text { Stover } \\
\text { yield } \\
\left(\mathrm{kg} \mathrm{ha}^{-1}\right)\end{array}$} \\
\hline & Grain & Stover & Grain & Stover & Grain & Stover & Grain & Stover & Grain & Stover & Grain & Stover & & \\
\hline \multicolumn{15}{|l|}{ Irrigations-3 } \\
\hline $\mathbf{I}_{0}:$ No irrigation & 1.51 & 0.78 & 44.7 & 60.5 & 0.32 & 0.20 & 9.7 & 16.0 & 0.31 & 0.96 & 9.4 & 74.1 & 2956 & 7665 \\
\hline $\begin{array}{c}I_{1}: \text { One } \\
\text { irrigation }\end{array}$ & 1.33 & 0.79 & 81.4 & 63.4 & 0.41 & 0.26 & 25.5 & 20.8 & 0.40 & 1.28 & 24.6 & 103.3 & 6092 & 8033 \\
\hline $\begin{array}{c}\mathbf{I}_{2}: \text { Two } \\
\text { irrigations }\end{array}$ & 1.36 & 1.27 & 83.4 & 110.7 & 0.44 & 0.28 & 26.8 & 24.2 & 0.47 & 1.21 & 28.7 & 105.2 & 6101 & 8669 \\
\hline SEm \pm & 0.06 & 0.07 & 3.5 & 3.1 & 0.02 & 0.01 & 4.0 & 2.5 & 0.01 & 0.02 & 1.7 & 4.6 & 63 & 53 \\
\hline $\mathrm{CD}(\mathrm{P}=\mathbf{0 . 0 5})$ & 0.14 & 0.19 & 14.0 & 12.3 & 0.04 & 0.02 & 1.5 & 3.8 & 0.02 & 0.05 & 6.8 & 18.0 & 247 & 266 \\
\hline \multicolumn{15}{|c|}{ N-levels $\left(\mathrm{kg} \mathrm{ha}^{-1}\right)-4$} \\
\hline $\mathrm{N}_{1}: 90$ & 1.39 & 0.83 & 61.2 & 65.6 & 0.46 & 0.23 & 20.4 & 18.8 & 0.37 & 0.78 & 16.5 & 62.1 & 4392 & 7878 \\
\hline $\mathrm{N}_{2}: 120$ & 1.40 & 0.96 & 67.6 & 77.4 & 0.44 & 0.26 & 21.5 & 21.3 & 0.39 & 1.15 & 19.3 & 92.0 & 4858 & 7989 \\
\hline$N_{3}: 150$ & 1.32 & 1.00 & 72.4 & 83.4 & 0.45 & 0.29 & 25.1 & 23.9 & 0.38 & 1.32 & 21.1 & 109.2 & 5462 & 8259 \\
\hline $\mathrm{N}_{4}: 180$ & 1.42 & 1.03 & 78.2 & 86.3 & 0.46 & 0.30 & 25.7 & 25.6 & 0.49 & 1.35 & 27.1 & 113.5 & 5486 & 8364 \\
\hline SEm \pm & 0.05 & 0.06 & 3.4 & 3.3 & 0.01 & 0.02 & 2.2 & 2.3 & 0.01 & 0.02 & 2.4 & 5.8 & 77 & 79 \\
\hline $\mathrm{CD}(\mathrm{P}=\mathbf{0 . 0 5})$ & 0.14 & 0.18 & 10.2 & 10.4 & 0.02 & 0.04 & 1.0 & 1.9 & 0.03 & 0.04 & 7.4 & 17.4 & 228 & 244 \\
\hline \multicolumn{15}{|l|}{ Interactions } \\
\hline \multicolumn{15}{|l|}{ I at $\mathbf{N}$} \\
\hline SEm \pm & 1.4 & 1.3 & 6.2 & 5.9 & 1.0 & 1.1 & 4.8 & 5.1 & 1.1 & 1.3 & 4.1 & 9.2 & 127 & 136 \\
\hline $\mathrm{CD}(\mathrm{P}=0.05)$ & N.S & N.S & N.S & N.S & N.S & N.S & N.S & N.S & N.S & N.S & N.S & N.S & 425 & 442 \\
\hline \multicolumn{15}{|l|}{ N at I } \\
\hline SEm \pm & 1.6 & 1.5 & 7.1 & 6.3 & 1.0 & 1.2 & 5.0 & 5.3 & 1.3 & 1.4 & 4.3 & 9.5 & 131 & 140 \\
\hline $\mathrm{CD}(\mathrm{P}=0.05)$ & N.S & N.S & N.S & N.S & N.S & N.S & N.S & N.S & N.S & N.S & N.S & N.S & 420 & 440 \\
\hline
\end{tabular}


Higher uptake of nutrients might be due to at higher fertility level promoted growth of roots as well as functional activity resulting in higher extraction of nutrients from soil environment to aerial parts (Heeta Sareen and Sharma, 2010). The interaction between irrigations and nitrogen levels was found to be non-significant.

\section{Phosphorus uptake (kg ha $\left.{ }^{-1}\right)$}

The data on phosphorus uptake by sorghum as influenced by irrigation levels and varying nitrogen levels are presented in Table 1. Two irrigations $\left(26.8 \mathrm{~kg} \quad \mathrm{ha}^{-1}\right)$ significantly increased the uptake of phosphorus in grain than no irrigation $\left(9.7 \mathrm{~kg} \mathrm{ha}^{-1}\right)$ but on par with one irrigation $\left(25.5 \mathrm{~kg} \mathrm{ha}^{-1}\right)$. With regards to stover, higher uptake of phosphorus was recorded with two irrigations $\left(24.2 \mathrm{~kg} \mathrm{ha}^{-1}\right)$ which was significantly superior to no irrigation $\left(16.0 \mathrm{~kg} \mathrm{ha}^{-1}\right)$ but on par with one irrigation $\left(20.8 \mathrm{~kg} \mathrm{ha}^{-1}\right)$.

The higher uptake of phosphorus at higher irrigation level might be due to rate of conversion of phosphorus into soluble form than that of insoluble form under lower irrigation level. This indicated that higher irrigation frequencies might have increased the solubility of phosphorus resulting into higher phosphorus uptake by the crop (Aulakh et al., 2013).

Phosphorus uptake by sorghum increased with increased levels of nitrogen. Nitrogen application at $180 \mathrm{~kg} \mathrm{ha}^{-1}$ resulted into higher absorption of phosphorus $\left(25.7 \mathrm{~kg} \mathrm{ha}^{-1}\right)$ in the grain than $120 \mathrm{~kg} \mathrm{~N} \mathrm{ha}^{-1}\left(21.5 \mathrm{~kg} \mathrm{ha}^{-1}\right)$ and 90 $\mathrm{kg} \mathrm{N} \mathrm{ha}{ }^{-1}\left(20.4 \mathrm{~kg} \mathrm{ha}^{-1}\right)$. In the stover higher uptake of phosphorus was recorded with 180 $\mathrm{kg} \quad \mathrm{N}$ ha $^{-1}\left(25.6 \mathrm{~kg} \mathrm{ha}^{-1}\right)$ which was significantly superior over $120 \mathrm{~kg} \mathrm{~N} \mathrm{ha}^{-1}(21.3$ $\left.\mathrm{kg} \mathrm{ha}^{-1}\right)$ and $90 \mathrm{~kg} \mathrm{~N} \mathrm{ha}{ }^{-1}\left(18.8 \mathrm{~kg} \mathrm{ha}^{-1}\right)$ but was found to be on par with $150 \mathrm{~kg} \mathrm{~N} \mathrm{ha}^{-1}$
(23.9 $\left.\mathrm{kg} \mathrm{ha}^{-1}\right)$. Increasing nitrogen application might have stimulated more vegetative growth and increased foraging capacity of roots which in turn increased the uptake of phosphorus (Gangadevi et al., 2012). The interaction between irrigations and nitrogen levels was found to be non-significant.

\section{Potassium uptake $\left(\mathrm{kg} \mathrm{ha}^{-1}\right)$}

The data on uptake of potassium by sorghum as influenced by irrigation levels and nitrogen levels are presented in Table 1.

Persual of data revealed that maximum potassium uptake of 28.7 and $105.2 \mathrm{~kg} \mathrm{ha}^{-1}$ (in grain and straw, respectively) was observed under two irrigations which was at par with one irrigation but significantly higher than no irrigation. The increased uptake of nutrients might be due to the supply of irrigation water leading to availability of adequate moisture in the soil which played an important role in nutrient uptake involving diffusion, mass flow and interception (Dutta et al., 2015).

Higher doses of nitrogen significantly influenced the potassium uptake. Higher potassium uptake (27.1 and $113.5 \mathrm{~kg} \mathrm{ha}^{-1}$ in grain and straw respectively) was recorded with180 kg N ha ${ }^{-1}$ was on par with $150 \mathrm{~kg} \mathrm{~N}$ $\mathrm{ha}^{-1}$ which was significantly higher compared to potassium uptake by 120 and $90 \mathrm{~kg} \mathrm{~N}^{-}$ ${ }^{1}$.Higher concentration and availability of nutrients in the rhizosphere might have led to higher uptake by the plant biomass (Mishra et al., 2015).

The interaction between irrigations and nitrogen levels was found to be nonsignificant.

The results were concluded that the highest concentration and uptake of major nutrients increased with increasing levels of $\mathrm{N}$ up to $180 \mathrm{~kg} \mathrm{~K} \mathrm{~K}_{2} \mathrm{O} \mathrm{ha}^{-1}$ but significant difference 
was observed at 120 and $150 \mathrm{~kg} \mathrm{~K}_{2} \mathrm{O} \mathrm{ha}{ }^{-1}$. In irrigation levels higher concentration and uptake of major nutrients was recorded with two irrigations significantly compared to one irrigation than no irrigation. The interaction between nitrogen and irrigation levels was non-significant in dry matter production and concentraction, uptake of major nutrients.

\section{References}

Aulakh, G.S., Krishan Kumar Vashist and Mahal, S. S. 2013a. Influence of irrigation regimes and nitrogen levels on root density, nutrient uptake and grain yield of August sown hybrid maize (Zea mays L.). International Journal of Plant Sciences. 8(2): 208214.

Dutta, D, Dutta Mudi, D, Murmu, P and Thentu, T. L. 2015. Response of ground- nut (Arachis hypogaea) to irrigation schedules, sulphur levels and sources in alluvial zone of west Bengal. Indian Journal of Agronomy. 60(3):443449.

Gangadevi, M., Sumathi,V., Tirumala Reddy, $S$ and Aruna, P. 2012. Influence of levels and time of nitrogen application on yield, nutrient uptake and postharvest nitrogen status of soil in aerobic rice. Current Biotica. 6(1):98-102.

Heeta Sareen and Sharma, G. L. 2010. Effect of plant densities and fertilizer levels on growth and NPZn uptake by extra early sorghum (Sorghum bicolor (L.) Moench) genotype. Annals of Agriculture Research New Series. 31(1 \&2):

Mathukia, R. K., Gohil, B. S., Mathukia, P. R and Chhodavadia, S. K. 2014. Optimization of irrigation and fertilizer for sweet corn (Zea mays L.Var. Saccharatasturt) under climate change conditions. Innovare Journal of Agricultural of sciences. 3(1): 1-3.

Mishra, J. S., Thakur, N. S., Pushpendra Singh, Kubsad,V. S., Kalpana, R., Alse, U. N and Sujathamma, P. 2015. Productivity, nutrient-use efficiency and economics of rainy- season grain sorghum (Sorghum bicolor) as influenced by fertility levels and cultivars. Indian Journal of Agronomy. 60 (1): 76-81.

\section{How to cite this article:}

Swami Chaitanya, T., P. Munirathnam, M. Srinivasa Reddy and Kavitha, P. 2017. Uptake of Major Nutrients of White Sorghum as Influenced by Irrigations and Different Levels of Nitrogen at Post-Harvest Stage. Int.J.Curr.Microbiol.App.Sci. 6(11): 1172-1176. doi: https://doi.org/10.20546/ijcmas.2017.611.140 